\title{
Przemiany w podmiejskich i śródmiejskich społecznościach lokalnych w procesie gentryfikacji
}

\section{KEYWORDS}

local community, gentrification, change, space, social relation

\begin{abstract}
Agnieszka Barczykowska, Przemiany w podmiejskich i śródmiejskich społecznościach lokalnych w procesie gentryfikacji [Suburban and downtown local community transformations in the gentrification process]. Kultura Społeczeństwo - Edukacja nr 2(20) 2021, Poznań 2021, pp. 27-42, Adam Mickiewicz University Press. ISSN 2300-0422, ISSN (Online) 2719-2717. DOI 10.14746/ kse.2021.20.2
\end{abstract}

The article presents socio-demographic, physical-functional and cultural-symbolic change aspects of chosen local communities in Poland, which aretheresult of the gentrification process, making itself real in their space. In the first part of the article information about genesis and the course of gentrification with the characteristic of the main actors' groups taking part in it is addressed. The second part of the article is devoted to the description of changes being experienced by local communities. Conclusions included in the end concentrate around consequences of progressive gentrification process for local communities and attempts to set a path to prevent negative aspect of theconsequences mentioned.

\section{Wstęp}

We współczesnym zatomizowanym, zmiennym i nieprzewidywalnym świecie społeczności lokalne pozostają wciąż przestrzeniami, które zapewniają człowiekowi

* ORCID: https://orcid.org/0000-0001-7443-0378. 
poczucie bezpieczeństwa, względnej stałości i przywiązania. Pozostają kluczowe dla budowania jego tożsamości indywidualnej i społecznej. Podobnie jak inne struktury społeczno-przestrzenne doświadczają zmian. Jednym z procesów, który doprowadza do wieloaspektowych przekształceń w społecznościach lokalnych, jest gentryfikacja, o której wiemy już dziś, że jest procesem o charakterze globalnym i przede wszystkim trwałym.

W Polsce gentryfikacja jest szczególnie widoczna w dwóch rodzajach przestrzeni: śródmieściach dużych miast oraz położonych $\mathrm{w}$ ich okolicach wsiach. Biorąc pod uwagę dane statystyczne ${ }^{1}$ (Szukalski, 2015: 2) oraz dotychczasową wiedzę o przebiegu tego procesu, można przyjąć, że są one dziś najdynamiczniej zmieniającymi się społecznościami lokalnymi, a co za tym idzie również środowiskami wychowawczymi. Dlatego też za cel niniejszego artykułu przyjęto przedstawienie zmian, jakie stają się udziałem podmiejskich i śródmiejskich społeczności lokalnych doświadczających procesu gentryfikacji. W artykule scharakteryzowane zostaną zmiany w sferze społeczno-demograficznej, fizyczno-funkcjonalnej oraz kulturalno-symbolicznej.

\section{Wielowymiarowość procesu gentryfikacji}

Proces gentryfikacji zajmuje uwagę badaczy już od niemal siedmiu dekad. Pierwsze opisy tego zjawiska wyszły w latach 60 . XX spod pióra Ruth Glass i Jane Jacobs, które niemal równocześnie stały się świadkami i bacznymi obserwatorkami powrotu do ścisłego centrum przedstawicieli klasy średniej. Było to o tyle zaskakujące, że stanowiło zaprzeczenie dotychczasowego trendu, zgodnie z którym osoby o wyższym statusie socjoekonomicznym wyprowadzały się ze zdegradowanych społecznie i architektonicznie, niebezpiecznych i niefunkcjonalnych stref śródmiejskich na przedmieścia, tam poszukując ciszy, spokoju i bezpieczeństwa. Obie badaczki ustosunkowały się do tych zmian nader krytycznie. Ich zdaniem przybycie nowych mieszkańców burzyło ład i porządek dzielnicy, mniej lub bardziej bezpośrednio zmuszając dotychczasowych rezydentów do zmiany miejsca zamieszkania. Przyniesiony przez gentryfierów styl życia, wartości, a przede wszystkim kapitały, z materialnym na czele, spowodowały drastyczne zmiany w wymiarze

\footnotetext{
${ }^{1}$ Szacuje się, że w Polsce w poddawanych procesom rewitalizacji i postępującej za nimi najczęściej gentryfikacji śródmiejskich dzielnicach żyje około 2 mln mieszkańców. Podobnie liczna jest grupa tych, którzy od początku XXI wieku wyemigrowali z miasta na wieś, a proces ten wciąż nie wygasł i nic nie wskazuje, żeby miało się tak stać przez co najmniej dwie, trzy dekady.
} 
społecznym, kulturowym, architektonicznym i polityczno-ekonomicznym (Glass, 2010: 7-9; Jacobs, 2014: 260).

Współcześnie, szukając wyjaśnień procesu gentryfikacji, zwraca się uwage przede wszystkim na czynniki natury ekonomicznej, rozwój gospodarki opartej na wiedzy i usługach, która lokuje miejsca pracy w centrach miast (tzw. wyjaśnienia podażowe) oraz istnienie „luki rentowej”, która powoduje, że w śródmieściach można nabyć ciekawe i atrakcyjne cenowo nieruchomości, stanowiące intratną inwestycję. Nie bez znaczenia są ułomności życia na przedmieściach: monotonia i gęstość zabudowy, czas i koszty dojazdów, niedostateczna infrastruktura, utrata elitarystycznego charakteru podmiejskich domostw, dla których oferta kulturalna, infrastrukturalna i społeczna śródmieścia stanowi atrakcyjną alternatywę (tzw. wyjaśnienia popytowe) (Grzeszczak, 2010: 27).

Jak już zostało wspomniane, pierwotnie proces gentryfikacji identyfikowano głównie w zdegradowanych centrach miast. W chwili obecnej w literaturze coraz częściej można spotkać się ze stanowiskiem, że procesy gentryfikacji toczyć się mogą również w przestrzeni wiejskiej, szczególnie położonej w okolicach wielkiego miasta. Wówczas dla opisania zjawiska używa się pojęcia greentryfikacji (Smith, Phillips, 2001: 457-469; Zwęglińska-Gałecka, 2020: 117). W chwili obecnej procesy gentryfikacji wsi są szczególnie zaawansowane w obszarze Europy Środkowo-Wschodniej, która z uwagi na sytuację polityczną po II wojnie światowej doświadczyła wyhamowania naturalnych procesów ekologicznych i dopiero w ostatniej dekadzie minionego wieku zaczęto obserwować w niej nasiloną migrację do wsi podmiejskich (Barczykowska, 2019: 204-211; Murzyn, 2006). Polska wpisuje się w te trendy - większy zasięg i dynamikę wydaje się mieć gentryfikacja $\mathrm{w}$ wiejskich obszarach podmiejskich. Oczywiście centra miast zmieniają się dynamicznie, ale wciąż więcej osób chce mieszkać pod miastem (Szukalski, 2015: 2; Kajdanek, 2011a, 2011b, 2012). Warto zwrócić uwagę, że tempo i zakres przekształceń wsi, czy szerzej mówiąc - terenów podmiejskich - powoduje, że stają się one jednymi z najdynamiczniej rozwijających się środowisk wychowawczych.

Proces gentryfikacji trwa w czasie, co znajduje odzwierciedlenie w przedstawianiu go w postaci następujących po sobie czterech faz: zwiastunowej, wczesnej, właściwej i zaawansowanej (Drozda, 2017: 52-53). Faza zwiastunowa związana jest $\mathrm{z}$ pojawieniem się $\mathrm{w}$ przestrzeni społeczności lokalnej nowych, młodych mieszkańców, zwykle o wyższym statusie społeczno-ekonomicznym, którzy szukają tanich mieszkań, klimatu, możliwości prowadzenia aktywnego życia. Przynoszą oni nie tylko nowe wzory życia, ale również potrzeby, przy czym charakterystyczna jest dla nich otwartość oraz szacunek dla lokalnej społeczności. Dość szybko włą- 
czają się oni w jej życie codzienne, dając początek tzw. wczesnej fazie gentryfikacji, która zwykle opiera się na współdziałaniu, albo przynajmniej nieprzeszkadzaniu sobie w działaniach, co pozwala powiedzieć, że gentryfikacja zachowuje emancypacyjny charakter (Grzeszczak, 2010: 67-70)². Dzięki działaniom gentryfierów poprawia się komfort życia większości mieszkańców. Są oni szczególnie aktywni w zakresie prowadzenia zmian przestrzeni architektonicznej (remonty, pojawianie się nowej infrastruktury) oraz podnoszenia jakości pracy instytucji (np. instytucje oświatowe, tj. szkoła, przedszkole). Działania te powodują, że zmienia się społeczny odbiór społeczności, która staje się atrakcyjna biznesowo i turystycznie. Trzeba jednak wyraźnie podkreślić, że ten typ gentryfikacji zdarza się niezwykle rzadko, a jeśli już się pojawia, to zwykle trwa krótko. Specyfiką gentryfikacji jest bowiem to, że w pewnym momencie zaczyna ona przypominać lawinę, która zmiata wszystko, co znajdzie się na jej drodze, bez względu na pierwotne znaczenie.

Polepszające się warunki życia w dzielnicy, wciąż wyraźnie dostrzegany koloryt powodują coraz większe zainteresowanie nie tylko ze strony pojedynczych osób, ale również podmiotów komercyjnych, np. deweloperów budowlanych i ich klientów. Do głosu dochodzą grupy silniejsze ekonomicznie i politycznie. Rozpoczyna się etap gentryfikacji właściwej, którego cechą rozpoznawczą jest dynamiczne kurczenie się przestrzeni dawnych mieszkańców, zmuszanych coraz częściej do wyprowadzek. Nowi mieszkańcy zdobywają przewagę, podporządkowując swoim potrzebom całą przestrzeń i społeczność. Zaczyna się gentryfikacja zaawansowana, co oznacza najczęściej, że po „starej” wersji dzielnic pozostaje niewiele, tak w wymiarze społecznym, architektonicznym, funkcjonalnym, jak i kulturowo-symbolicznym.

Dla przebiegu gentryfikacji, choć dotyka społeczności w wielu aspektach, kluczowe wydają się być procesy społeczne. Dlatego dla jej zrozumienia niezbędne jest poznanie grup biorących w niej udział. Generalnie można wyodrębnić dwie grupy: gentryfierów i rdzennych mieszkańców, zwanych również autochtonami. Jest to podejście mocno uproszczone, bo ani jedna, ani druga grupa nie jest homogeniczna, zaś jej kształt zależy nie tylko od etapu gentryfikacji, ale również charakteru i lokalizacji społeczności jej doświadczającej.

Od początku refleksji nad procesami gentryfikacji przyjmuje się, że rdzenni mieszkańcy należą do grup lokujących się na najniższych szczeblach drabiny spo-

${ }^{2}$ O gentryfikacji emancypacyjnej mówi się w sytuacji, gdy rdzenni mieszkańcy są włączani $\mathrm{w}$ proces zmian w pozycji partnerów, gdzie na równi z nowymi mieszkańcami korzystają z benefitów zmian. Podkreśla się jej równościowych charakter, wzmocniony brakiem lub niewielkimi wysiedleniami. Struktura społeczna pozostaje heterogeniczna. Przeciwieństwem jest gentryfikacja rewanżystowska, w którą wpisany jest konflikt, polaryzacja i wykluczenie grup socjoekonomicznie słabszych. 
łecznej, niejednokrotnie doświadczając marginalizacji z uwagi na występowanie wśród nich problemów z obszaru patologii społecznej (bezrobocie, uzależnienia, przestępczość itd.). Badania potwierdzają, że część autochtonów wpisuje się w zakres marginesu, ale większość mieszkańców gentryfikujących obszarów to tzw. „normalsi”, choć charakteryzujący się dość niskim statusem socjoekonomicznym. Podejmują oni zadania wynikające z przypisanych im ról społecznych i nie przejawiają znamion patologii społecznej (Barczykowska, 2019: 259-262). Część z nich można zakwalifikować jako „pracujących biednych” (working poor) ${ }^{3}$. Grupa ta jest dość bierna społecznie, również ze względu na obciążenie pracą. Zamieszkują oni zdegradowane dzielnice często z powodu „blokady mobilności” spowodowanej uwarunkowaniami zewnętrznymi (np. ceny mieszkań, polityka mieszkaniowa) (Nóżka, 2016: 155-161). Większość z nich stanowią osoby w wieku średnim oraz seniorzy.

Gentryfierzy stanowią przeciwieństwo rdzennych mieszkańców. Są to osoby młode, dobrze wykształcone, wykonujące zwykle prestiżowe zawody, o wysokich dochodach. Cenią kosmopolityczne wartości, dostrzegają uroki miejskiego życia, krytycznie patrzą na życie na przedmieściach. Są aktywne towarzysko i społecznie, wykorzystują przestrzenie miasta do zaspokojenia swoich potrzeb (Gądecki, 2012: 42-43). W przypadku gentryfierów miejskich głównym motywem zamieszkania $\mathrm{w}$ centrum jest dostęp do miejsca pracy oraz miejskich atrakcji, co pozwala na prowadzenie intensywnego życia towarzysko-kulturalnego. Gentryfierzy wiejscy poszukują lepszych warunków życia i wychowania dzieci. Cenią naturę i bliskie relacje. Ważny jest dla nich element ekonomiczny - wieś daje więcej za mniej. Seniorzy na wsi szukają spokojnej przystani na starość (Bijker, Haartsen, Strijker, 2012: 490-498; Kowalczuk, 2015: 7). Wśród gentryfierów można wyodrębnić dwie podgrupy: pionierów oraz gentryfierów właściwych, przy czym ostatnią grupę tworzą gentryfierzy konsumpcyjni i produkcyjni. Do grupy konsumpcyjnych zaliczamy yupps, yuppie oraz przedstawicieli klasy kreatywnej, zaś do produkcyjnych międzynarodowe koncerny, prywatnych inwestorów oraz władze miasta (Barczykowska, 2019: 187).

Jeśli chodzi o śródmieście, zwykle jako pierwsi pojawiają się w nim gentryfierzy pionierzy. To zwykle osoby samotne lub młode pary, niekiedy opisywane jako dinks (double income, no kids - bezdzietni, z podwójnym dochodem), przedstawiciele „wolnych” zawodów (artyści, dziennikarze), przedstawiciele mniejszości seksualnych, turyści, którzy postanowili w mieście pozostać na dłużej, a także stu-

${ }^{3}$ Oznacza to, że podejmują i podtrzymują oni aktywność zawodową (najczęściej w formie niestandardowego zatrudnienia), ale dochody z niej pochodzące są na tyle niskie, że nie pozwalają na zaspokojenie potrzeb, wymuszając zastosowanie dodatkowych strategii pozwalających się utrzymać. 
denci. Do zaniedbanych, ale w miarę stabilnych społecznie dzielnic przyciągają ich klimatyczne i finansowo atrakcyjne przestrzenie, bowiem nie należą oni do grona osób najbardziej majętnych (Grzeszczak, 2010: 118-120). Szukają przestrzeni tolerancyjnych, w których będą mogli eksponować swoją niepowtarzalność, rozwijać swoje talenty. Wynajmują, nieco rzadziej kupują domy, mieszkania i odnawiają je na własny użytek, wykorzystując w tym celu „kapitał potu” (Drozda, 2017: 57). „Ich obecność nadaje okolicy «wyluzowany», artystyczny klimat, sławę miejsca modnego, w którym spotyka się bohema" (Groyecka, 2014: 18). Dominujący u nich kapitał społeczny powoduje, że dość szybko integrują się ze społecznością, stając się jej naturalnym ogniwem. Ich nie do końca konwencjonalny styl życia dość dobrze wpisuje się w otwartość tych obszarów. Pionierami są również studenci, których pojawienie się $\mathrm{w}$ zdegradowanych przestrzeniach śródmiejskich określa się mianem studentyfikacji. Oznacza ona swoistą „kolonizację” przestrzeni przez ludzi młodych, którzy znajdują w niej miejsce do życia, zarobkowania i realizacji swoich potrzeb towarzysko-rozwojowych. Ich obecność jest już dość mocno odczuwalna dla wspólnoty lokalnej, głównie z uwagi na odmienny tryb życia.

Coraz lepszy klimat wokół dzielnicy przyciąga do niej kolejne grupy gentryfierów: yuppies (young urban professional), związanych ze światem bankowości i innych profesjonalnych usług, oraz yupps (young urban professionalparents), czyli dobrze sytuowanych rodziców łączących karierę zawodową z życiem rodzinnym. Stanowią oni tzw. grupę pionierów konsumpcyjnych. Koncentracja na karierze zawodowej, szeroki zakres sieci społecznych i duża mobilność powodują, że grupa ta nie jest zainteresowana integracją ze starymi mieszkańcami. Yuppies i yupps wytwarzają własny, odizolowany od starych mieszkańców świat, co wyraża się choćby w preferowaniu grodzonych posesji, głównie nowych „plomb” lub wyremontowanych kamienic jako miejsc zamieszkiwania. Sąsiedztwo, choć nie stanowi ważnego punktu w ich relacjach społecznych, ma jednak potwierdzać wysoki statusu społeczno-ekonomiczny (Szlendak, 2010: 14). Bywa, że podejmują oni wobec starych mieszkańców działania „wychowawcze”, dążąc do wyeliminowania jednostek i zachowań, które nie pasują do ich wyobrażenia dzielnicy. Gentryfierzy konsumpcyjni oczekują od dzielnicy już nie tylko klimatu, ale również możliwości zaspokojenia swoich potrzeb, co pociąga za sobą proces tzw. yuppifikacji lokalnego biznesu. Szewc, lokalny sklepik, bar mleczny, niewielka rodzinna apteka zastają zastąpione przez usługodawców odpowiadających gustom nowych mieszkańców, najczęściej w postaci globalnych sieci. Z kolei yupps, poza szybkim dojazdem do pracy, oczekują zaspokojenia potrzeb związanych z wychowaniem dziecka, w postaci przedszkola, dobrej szkoły, dostępu do instytucji zapewniających możliwości opieki oraz rozwoju. Co jednak znamienne, lokalną szkołę najczęściej ignorują, nie dostrze- 
gając w niej potencjału. Decydują się na dojazdy do instytucji, które w ich ocenie zapewnią dzieciom odpowiedni poziom edukacji oraz socjalizację w adekwatnym środowisku rówieśniczym. Rosnący potencjał przekształcającej się społeczności szybko zostaje dostrzeżony również przez „większych graczy”, np. deweloperów i inwestorów, którzy poprzez budowę nowych kompleksów usługowych i mieszkaniowych wprowadzają do dzielnicy gentryfierów produkcyjnych. Ta grupa kupuje nieruchomości w dzielnicy nie po to, by w nich zamieszkać, ale wygenerować jak największy zysk. Grupa ta jest postrzegana jako główna przyczyna intensyfikacji wysiedleń starych mieszkańców (Sinewali, 2010: 14), co nie do końca jest prawdą, bo te mają miejsce na każdym etapie gentryfikacji.

Nieco inny portret gentryfierów można naszkicować, patrząc na tych, którzy osiedlają się na wsiach. Prowadzone przez Martina Phillipsa badania pokazały, że jest to grupa o mniej homogenicznych właściwościach klasowych. Wiejscy gentryfierzy to głównie rodziny z dziećmi, zdecydowanie rzadziej osoby w wieku emerytalnym lub przedemerytalnym oraz bezdzietne pary (Phillips, 1993: 123-140). Dla tej grupy społecznej istotniejsze jest znalezienie dogodnych warunków do życia rodzinnego, stąd większe znaczenie ma dla niej wielkość i atrakcyjność zajmowanych przestrzeni, ale jest ona również zainteresowana lokalnym kontekstem, dziedzictwem i kulturą. Badania pokazują, że relatywnie lepiej odnajdują się oni w relacjach ze starymi mieszkańcami, szybciej stają się ogniwami społeczności lokalnej, choć nie brakuje również takich, dla których dom na wsi pozostaje jedynie miejscem do spania (Kajdanek, 2011a: 14; Śpiewak, 2016: 146-147). Opisując wiejskich gentryfierów i odwołując się do kategorii użytych przy charakterystyce ich miejskich odpowiedników, można powiedzieć, że łączą w sobie cechy gentryfierów pionierów i konsumpcyjnych. Szanują zwykle rdzennych mieszkańców, są w stanie dzielić z nimi przestrzeń, której na wsi jest odpowiednio dużo. Dzięki temu wiejscy autochtoni bardzo rzadko doświadczają zjawiska wypierania. Należy również podkreślić, że w obszarach wiejskich nie ma najczęściej tak znaczących dysproporcji ekonomicznych między starymi i nowymi mieszkańcami, bo starzy mieszkańcy bogacą się, sprzedając ziemię kolejnym osadnikom. Znacząco zmienia to relacje między obiema grupami, które zwykle traktują się po partnersku. To wszystko powoduje, że proces gentryfikacji przebiega spokojniej, a jego negatywne następstwa są ograniczone.

Proces gentryfikacji zmienia nie tylko strukturę społeczno-demograficzną społeczności, ale przynosi również zmiany fizyczno-funkcjonalne oraz kulturalno-symboliczne. Badania pokazują, że ich przebieg jest nie tylko zróżnicowany przez typ środowiska (miasto vs. wieś), ale ma również rys lokalny. Można powiedzieć, że procesy gentryfikacji zachowują pewien wspólny kierunek i charakter 
zmian, ale właściwości poszczególnych społeczności lokalnych (położenie, historia, skład społeczny, pełnione funkcje itd.) nadają procesom niepowtarzalny charakter. Spróbujmy odtworzyć te zmiany, zaczynając od tych o charakterze społeczno-demograficznym.

\section{Przemiany społeczno-demograficzne gentryfikujących społeczności lokalnych}

Zmiany w profilach społeczno-demograficznych wspólnot lokalnych dokonują się poprzez sygnalizowane wcześniej (1) przybywanie do społeczności ludności o wyższym statusie społeczno-ekonomicznym, co skutkuje najczęściej (2) wypieraniem słabszych społeczno-ekonomicznie rdzennych mieszkańców, czego efektem jest (3) odmłodzenie populacji, zahamowanie procesu starzenia, pojawienie się dzieci oraz (4) podniesienie jej statusu społeczno-ekonomicznego (Barczykowska, 2019: 251). Finałem wskazanych wyżej procesów jest odwrócenie „gradientu społecznego" (Grzeszczak, 2010: 12).

Pierwszą ze zmian, jakie dokonują się w społeczności pod wpływem gentryfikacji, jest jej odmłodzenie oraz podniesienie odsetka dzieci w populacji. Jak już zostało wspomniane, gentryfierzy są grupą demograficznie młodą. Tworzą ją najczęściej osoby między 30 a 40 rokiem życia, przy czym w mieście znaczącą siłę stanowią również studenci, a więc osoby do 25 roku życia. Gentryfierów miejskich i wiejskich różni sytuacja rodzinna. O ile wśród grupy zamieszkującej centra miasta najczęściej pojawiają się single lub osoby w związkach nieformalnych, bezdzietne, to w przypadku wsi dominują osoby w stabilnych związkach, często już z dziećmi, łączące pracę zawodową z życiem rodzinnym. Co ciekawe, i w jednym i w drugim środowisku w zasadzie nie spotyka się rodzin wielopokoleniowych. W tej drugiej lokalizacji pojawiają się również osoby w wieku emerytalnym. Nie stanowią one jednak na tyle silnej grupy, by odwrócić tendencję odmładzania społeczności.

Drugą zmianą jest podniesienie statusu społeczno-ekonomicznego społeczności. Grupę gentryfierów charakteryzuje dobra i stabilna sytuacja zawodowa i tym samym materialna, które pozwalają im na migrację w poszukiwaniu coraz lepszych lokalizacji. Nowi mieszkańcy potrzebują przestrzeni dla siebie. Na ich potrzeby odpowiadają właściciele lokali, nie tylko podnosząc ich standard, ale również rozszerzając dostępną ofertę. Najczęściej dzieje się to poprzez proces wypierania starych mieszkańców. Remonty, odzyskiwanie kamienic przez spadkobierców, związane z tym coraz wyższe czynsze, sprzedaż kolejnych domów w prywatne ręce powodują, że rynek nieruchomości rośnie i staje się coraz mniej przyjazny rdzennym 
mieszkańcom (Lees, 2008: 2451). Ponieważ relatywnie niewiele osób ma tytuły własności do nieruchomości, poprzez wzrost czynszów nowi właściciele doprowadzają do wyprowadzek rdzennych mieszkańców. Wraz z nimi zmniejsza się skala problemów socjalnych.

Trzecią kwestią, o której warto wspomnieć w aspekcie społeczno-demograficzym, są zmiany w relacjach między grupami dzielącymi przestrzenie doświadczające procesu gentryfikacji. Analizując ten proces, Tim Butler i Loretta Leess twierdzili, że relacje społeczne zmieniają się wraz z nadchodzeniem kolejnych fal gentryfikacji. W ich ocenie, o ile pionierzy gentryfikacji pierwszej i drugiej fali są zazwyczaj skłonni do życia w zróżnicowanej społeczności, akceptowania odmienności, o tyle gentryfierzy trzeciej i czwartej fali takiej otwartości na inność już w sobie nie mają. Tych ostatnich charakteryzuje zdecydowanie silniejsza orientacja indywidualistyczna, dążenie do homogenizacji stosunków społecznych oraz zgoda na eliminację tych, którzy do określonego wzoru nie pasują (Butler, Lees, 2006: 467-487). W konfrontacji z nimi starzy mieszkańcy mają niewielkie możliwości działania, stąd najczęściej biernie poddają się biegowi zdarzeń. Oddają symbolicznie i fizycznie pole gentryfierom, którzy kształtują ład dzielnicy w zależności od własnych potrzeb. Komentując działania gentryfierów, Nicholas Blomley (2003: 9) zauważył w nich znamiona przemocy symbolicznej, która wyraża się w narzucaniu rdzennym mieszkańcom reguł i wartości, formułowaniu wobec nich określonych oczekiwań i wymuszaniu dopasowania się do nich, ignorowaniu potrzeb i ich samych. Chęć opanowania „dzikiego” miasta, przywrócenia ładu i porządku, zdaniem Neila Smitha (1996: 17-18) pozwala niebezpiecznie przesuwać granice działań i doprowadza do jawnych nieprawidłowości i niesprawiedliwości, czego przykładem mogą być znani z rodzimej rzeczywistości „Czyściciele kamienic”.

Nieco inaczej kształtują się relacje między gentryfierami a rdzenną ludnością w przestrzeniach wsi podmiejskich. W większości badań na przebiegiem gentryfikacji wiejskiej nie stwierdza się wypierania fizycznego starych mieszkańców, choć możliwe są procesy ich marginalizacji lub samoizolacji obu grup (Zwęglińska-Gałecka, Hasik, 2018: 425-430; Barczykowska, 2019: 328-333). To, jak ułożą się relacje między obiema grupami zależy w dużej mierze od tego, jaka forma osiedlania pojawia się jako dominująca w procesie gentryfikacji oraz jakie strategie przybiorą gentryfierzy wobec rdzennych mieszkańców i społeczności.

Jeśli chodzi o kwestie form zamieszkiwania na przedmieściach Katarzyna Kajdanek (2011b: 305-306) wyróżniła trzy rodzaje osiedli: 1) wsie ex-rolnicze, które $\mathrm{z}$ uwagi na kurczenie się pierwotnej funkcji oraz wyludnianie, przy jednoczesnej bliskość miasta stały się atrakcyjną lokalizacją mieszkaniową; 2) zaplanowane osiedla deweloperskie, stanowiące niemal oddzielne organizmy oraz 3) miasteczka 
satelickie. Najwięcej okazji do wzajemnych kontaktów odnotowuje się w pierwszym i trzecim z rodzajów osiedli, tam bowiem jest najwięcej przestrzeni i wspólnych spraw do rozwiązania. Jednocześnie funkcjonowanie na relatywnie małym obszarze, przy odmiennych potrzebach, stylach życia i oczekiwaniach tworzy pole do konfliktów, które skutkować mogą marginalizacją lub (samo)izolacją grup. W drugim rodzaju osiedla szanse na spotkanie i współpracę starych i nowych mieszkańców są bardzo ograniczone, bowiem ich potrzeby i szlaki komunikacyjne nie przecinają się. Starzy i nowi mieszkańcy żyją obok siebie.

Analiza wyników badań nad procesem gentryfikacji pozwala wskazać trzy dominujące strategie prezentowane przez gentryfierów, jeśli chodzi o relacje z rdzennymi mieszkańcami ${ }^{4}$. Pierwszą grupę stanowią „społecznicy”, wśród których można wyróżnić „pionierów” i „zorientowanych”. Obie grupy są otwarte na kontakty z ludnością rdzenną, chętnie wchodzą z nią w zróżnicowane relacje. „Społecznicy pionierzy” rekrutują się zwykle z tych, którzy do społeczności przybyli jako pierwsi. To osoby, które chętnie i poprzez bezpośrednie interakcje działają na rzecz społeczności, mając na względzie interes całej wspólnoty. Można odnieść wrażenie, że dla tej grupy zaangażowanie w życie społeczne stanowi próbę wykreowania „swojego miejsca”, budowania własnej tożsamości. „Społecznicy zorientowani” to ci, dla których motorem do działania jest jakaś (najczęściej ich) potrzeba. $\mathrm{Z}$ tego powodu zaangażują się $\mathrm{w}$ działania na rzecz szkoły czy przedszkola, będą walczyć o kanalizację lub nową drogę. Założą stowarzyszenie, by stać się równorzędnym partnerem do rozmów z lokalnymi władzami. Zdecydowanie rzadziej włączą się jednak w pracę takich organizacji, jak koło gospodyń wiejskich, ochotnicza straż pożarna, zespół ludowy czy grupa miłośników lokalnego folkloru, co jest właściwe „pionierom”. Kolejną grupę określić można jako „społeczników konformistycznych” lub „okazjonalnych”, którzy chętnie włączają się w doraźne działania, które wymagają co najwyżej obecności. Dla nich przestrzenią do działania są festyny lub akcje charytatywne. Czują się wówczas częścią społeczności, ale na co dzień nie dążą do potwierdzenia tego poprzez podejmowanie działań. W gentryfikujących społecznościach pojawiają się również osoby „neutralne”, które poza konwencjonalnymi gestami nie angażują się we wspólnotę. Ze społecznością lokalną dzielą tylko przestrzeń $\mathrm{i}$ to też w ograniczonym, wręcz niezbędnym wymiarze. Obrazu dopełniają gentryfierzy „izolujący się”, którzy nie tylko nie podejmują niemal żadnych kroków, by w społeczności zaistnieć, a wręcz starają się od wspólnoty odizolować. O tych

\footnotetext{
${ }^{4}$ Prezentowana typologia jest efektem analizy licznych badań nad zjawiskiem gentryfikacji i stanowi autorskie ujęcie zagadnienia.
} 
ostatnich grupach Katarzyna Kajdanek pisze - odwołując się do koncepcji „kultury unikania” - że nie dążą oni do bycia częścią społeczności, bo to by wiązało się z koniecznością nawiązywania i utrzymywania gęstej sieci relacji społecznych, rozszerzenia dostępu do sfery prywatności, prowadzenia jakiejś formy życia zbiorowego, regulowanego normami i systemem wartości, którego się nie negocjuje. Ta grupa nie jest „(...) w stanie zaakceptować społecznych kosztów silnych powiązań międzyludzkich” (Kajdanek, 2011a: 46, 48; 2011b: 311-312). Do podobnych wniosków doszedł Marcin Wójcik. Wśród badanych przez niego nowych mieszkańców wsi zdecydowana większość deklarowała poczucie przywiązania do wsi jako miejsca, przy jednoczesnej obojętności wobec społeczności lokalnej. Byli gotowi do użytkowania tej samej przestrzeni, lecz bez form integracji społecznej (Wójcik, 2013: 135). Przyczyną tego stanu rzeczy są silne związki z miastem, w którym osoby te realizują przeważającą część swoich potrzeb. Dom na wsi jest przede wszystkim miejscem do spania i odpoczywania lub ewentualnie spotkań z gośćmi spoza społeczności.

Podsumowując, opisane zmiany prowadzą w pierwszym okresie gentryfikacji do heterogenizacji struktury społecznej, by w kolejnych etapach ją spolaryzować. Finalnie struktura staje się na nowo homogeniczna, ale jej parametry są zdecydowanie różne od wyjściowych. Po procesie gentryfikacji społeczność jest odmłodzona, lepiej sytuowana, z biegiem czasu również bardziej dzietna.

\section{Przemiany fizyczno-funkcjonalne gentryfikujących społeczności lokalnych}

Postępujące zmiany społeczno-demograficzne znajdują odzwierciedlenie w przestrzeni fizycznej oraz w funkcjach pełnionych przez społeczności lokalne. Zwykle prowadzą one do odnowienia substancji mieszkaniowej, uzupełnienia sieci instytucji, podniesienia funkcjonalności działających instytucji. Znajduje to przełożenie w rosnącej jakości życia, ale także w cenach nieruchomości, tak w najmie, jak i sprzedaży. Bez wątpienia jednym z efektów gentryfikacji jest porządkowanie przestrzeni, przywracanie jej dawnego blasku, odkrywanie uśpionych potencjałów. Równocześnie w literaturze przedmiotu zaznacza się, że gwałtowny rozrost inwestycji prowadzić może do dezintegracji struktury przestrzennej. Najczęściej powodem tego jest proces „dogęszczania”, w ramach którego powstaje zabudowa nieprzystająca do charakteru i tradycji społeczności. Jak słusznie zauważa Piotr Zierke, stwarza to „poważne zagrożenie zaniku lokalnych tradycji budowlanych oraz utraty wielowiekowej spuścizny architektonicznej” (Zierke, 2016: 101-113). 
Procesy te widoczne są w śródmieściach, ale również na terenach podmiejskich, szczególnie tam, gdzie kreatorem przestrzeni stają się deweloperzy, promujący homogeniczną zabudowę mieszkaniową, niejednokrotnie pozbawioną koniecznej infrastruktury transportowej, usługowej, medycznej, ale również i oświatowej (Stelmaszewska, 2020: 28).

Wprowadzenie się nowych mieszkańców, o odmiennych stylach życia i potrzebach, skutkuje przemianami funkcjonalnymi. Dotychczas zdegradowane obszary śródmiejskie zaczynają pełnić funkcje kulturotwórcze oraz turystyczno-rekreacyjne, czasami wręcz reprezentacyjne. Przykładami mogą być poznańskie Śródka i coraz bardziej Jeżyce, krakowski Kazimierz czy warszawskie Praga i Powiśle. Z kolei w obszarze wsi podmiejskich wraz z wyprzedażą ziemi zaczynają zanikać funkcje rolniczo-produkcyjne, a rozszerzają się rekreacyjno-rezydencjalne. Tak na wsi, jak i w mieście zmienia się profil usług, które zgodnie z regułami rynkowymi zorientowane zostają na konsumentów z wyższym kapitałem, czyli gentryfierów. Niejednokrotnie nieadekwatność nowych funkcji i idących za tym usług do potrzeb, możliwości i oczekiwań starych mieszkańców i jednocześnie dążenia nowych mieszkańców do zaspokojenia swoich oczekiwań prowadzi do ostrych konfliktów społecznych lub wręcz marginalizacji grup słabszych.

Podsumowując, zwykle gentryfikacja zmienia przestrzeń fizyczną na lepsze. Staje się ona uporządkowana, bezpieczniejsza, lepiej dopasowana do użytkowników. Ale zmiany te mogą i zwykle zostają zaburzone przez potrzebę maksymalizacji zysków, co skutkuje pojawieniem się budynków i infrastruktury niedopasowanej do okoliczności.

\section{Przemiany kulturalno-symboliczne gentryfikujących społeczności lokalnych}

Przybywanie do społeczności lokalnej nowych mieszkańców znacznie różniących się statusem, stylem życia, wartościami, idące za tym wywieranie przez nich coraz większego wpływu na wspólnotę powoduje najczęściej utratę przez nią tożsamości kulturowo-społecznej. Jest to z jednej strony wynik rozluźniania więzi społecznych, będący efektem wysiedleń oraz tendencji polaryzacyjnych grup uczestniczących $\mathrm{w}$ procesach gentryfikacji. Z drugiej strony procesy gentryfikacji stają się kołem zamachowym postępującej komercjalizacji przestrzeni. Oba procesy są szczególnie widoczne w społecznościach śródmiejskich, które stając się często „produktami” dopasowanymi do potrzeb określonej grupy użytkowników (np. turystów), zatracają swój dotychczasowy, wyjątkowy charakter. Co jednak 
znamienne w opinii użytkowników miasta, którzy do tej pory nie byli związani $\mathrm{z}$ jego centrum, zachodzące $\mathrm{w}$ nim zmiany postrzegane są pozytywnie, bo oto na ich oczach zaniedbana do tej pory dzielnica ze względu na jej walory rozrywkowe, rekreacyjne, czy turystyczne zmienia się w godną uwagi. W wielu wypadkach takie obszary zaczynają pełnić rolę (pop)kulturotwórczą.

Zmiany symboliczno-kulturowe dokonują się również w odniesieniu do wsi podmiejskich, które ze środowiska nieatrakcyjnego, kojarzonego z zacofaniem, stają się pożądaną, obfitującą w wiele zalet i profitów lokalizacją. Najpełniej zmianę stosunku do wsi oddaje wypowiedź rodowitego mieszkańca jednej z podolsztyńskich wsi: „Gdy byłem w liceum, koledzy patrzyli na mnie z politowaniem i nazywali wieśniakiem. Teraz patrzą na mnie z zazdrością i nazywają bogatym, bo mieszkam na wsi blisko miasta. A ja wciąż mieszkam w tym samym domu" (Źróbek-Różańska, Zysk, 2015: 133). Dzieje się tak, bo posiadanie domu pod miastem lub w innej cenionej lokalizacji pozostaje jednym z ważniejszych wyznaczników sukcesu życiowego (Leśniak-Rychlak, 2018/2019: 221; Kajdanek, 2014: 190192). Jak pisze Henryk Domański (2012: 43-44): „Sygnałem przynależności do klasy średniej jest posiadanie «właściwego» adresu (...)”. Dla wielu gentryfierów, zwłaszcza w początkowym okresie zamieszkiwania, wieś jawi się jako bezproblemowa wspólnota, w której życie upływa z dala od kłopotów, gdzie wartości są powszechnie podzielane i nienaruszalne, mieszkańcy zaś egzystują w zgodzie z innymi ludźmi i przyrodą, stanowiąc uosobienie cnót. Co jednak znamienne, coraz więcej osób dostrzega problemy, jakie wiążą się z podmiejskim życiem, czego następstwem jest decyzja o powrocie do miasta, dodajmy - do jego ścisłego centrum (Kajdanek, 2019: 53-62).

\section{Gentryfikacja społeczności lokalnej - bilans zysków i strał}

Procesy gentryfikacji zajmują teoretyków i badaczy już ponad pół wieku. Choć przyjmuje się, że mają one charakter globalny, nie można zaprzeczyć, że to na poziomie lokalnym są najbardziej widoczne jej konsekwencje. Gentryfikacja wymyka się jednoznacznym ocenom. Będą się one zmieniać w zależności od tego, o jakim obszarze i w jakim czasie będziemy mówić. O gentryfikacji można powiedzieć, że jest niczym lek homeopatyczny - w niewielkiej dawce może być ożywcza i lecznicza, ale jej nadmiar prowadzić może do poważnych powikłań. Raz uruchomiona nie ma niestety w sobie mechanizmów samoograniczających i w związku z tym rzadko kiedy bilans jest wyłącznie pozytywny. Wśród pozytywnych konsekwencji gentryfikacji wskazuje się przede wszystkim rozbijanie monokultur ubóstwa i wy- 
kluczenia, szczególnie jeśli chodzi o obszary śródmiejskie, oraz postępującą wraz z pojawianiem się nowych mieszkańców heterogenizację sąsiedztwa (co wiemy ma miejsce tylko w początkowej fazie procesu). W zasadzie w większości gentryfikujących obszarów obserwuje się stabilizację demograficzną, z tendencją do odmłodzenia oraz zwiększenia liczebności populacji. Wraz z nowymi mieszkańcami napływają środki finansowe, które inwestowane w najbliższe otoczenie przyczyniają się do podniesienia jakości życia w wymiarze fizycznym, społecznym i kulturalnym. Społeczności zyskują na wartości, podnosi się ich waloryzacja, stają się miejscami pożądanymi do życia i do „bywania”. Z perspektywy szerszej przestrzeni zaczynają funkcjonować jako miejsca ważne. Gentryfierzy, zwłaszcza ci pierwsi, stanowią niejednokrotnie impuls do rozwoju życia społecznego, uruchomienia uśpionych sił społecznych. Definiują potrzeby i oczekiwania mieszkańców i potrafią skutecznie zabiegać o ich realizację. To głównie z ich inicjatyw i dla zaspokojenia ich potrzeb w społeczności pojawiają się nowe instytucje i usługi, co podnosi funkcjonalność obszaru. Powstające miejsca pracy pozwalają na zmniejszenie obciążeń socjalnych. Zainteresowanie społecznością, zaangażowanie w jej sprawy wzmacnia nieformalne i formalne mechanizmy kontroli społecznej. Wymienione pozytywy nie pojawiają się automatycznie. Wydaje się, że prawdopodobieństwo ich zaistnienia jest zdecydowanie wyższe w pierwszych etapach gentryfikacji oraz w takich społecznościach lokalnych, gdzie różnica w szeroko rozumianych kapitałach ludności rdzennej i gentryfierów jest względnie niewielka. Wyniki badań pokazują, że jest to stan, który zwykle trwa dość krótko, ma charakter przejściowy, jeśli proces gentryfikacji nie zostanie zahamowany lub poddany kontroli, co jest zadaniem niezwykle trudnym. Im bardziej zaawansowana gentryfikacja i im bardziej odmienne profile nowych i starych mieszkańców, tym szybciej pojawiają się negatywne konsekwencje procesu. W ostatnich etapach gentryfikacji nieuniknionym następstwem jest rozluźnienie więzi społecznych, coraz bardziej płynna tożsamość przestrzenna, a dalej osłabienie kontroli społecznej. Odmienne interesy, potrzeby i styl życia stają się przyczyną nieustannych napięć i konfliktów, z których zwykle zwycięsko wychodzą silniejsi kapitałowo gentryfierzy. Wzmacnia to podział na starych i nowych, ujawnia kolejne podziały i nierówności, prowadząc do marginalizacji rdzennej części społeczności. Społeczność zostaje zwykle podporządkowana nowym mieszkańcom, zmieniają się jej funkcje, z których część zaczyna wykraczać poza zasięg społeczności. Wzrost znaczenia i atrakcyjność społeczności w szerszej perspektywie przyciąga coraz silniejszych graczy, tworząc często pole do nadużyć i spekulacji. Z biegiem czasu maleje znaczenie społeczności, rozprzestrzenia się syndrom NIMBY. Społeczność zaczyna przeistaczać się w zbiorowość. 
Procesy gentryfikacji bez wątpienia mają w sobie ogromny potencjał, którego efektem mogą być spektakularne zmiany społeczności. Nie można jednak tracić z oczu kosztów, jakie mogą stać się udziałem dotkniętych nimi wspólnot, co jest tym ważniejsze, że gentryfikacja jest procesem, który wpływa na całokształt życia społeczności lokalnej. Zadaniem przedstawicieli nauk społecznych jest nie tylko poznanie charakteru tego procesu, ale przede wszystkim umiejętne nim zarządzanie. Gentryfikacja może przynieść społeczności wiele zysków, ale z uwagi na jej charakter nie można postawiać jej bez nadzoru.

\section{Bibliografia}

Barczykowska A. (2019), Systemy wychowawcze gentryfikujących społeczności lokalnych. Rozpadstagnacja - rozwój, Poznań.

Bijker R.A., Haartsen T., Strijker D. (2012), Migration to Less-Popular Rural Areas in the Netherlands: Exploring the Motivations, Journal of Rural Studies, vol. 28, s. 490-498.

Blomley N. (2003), Unsettling the City: Urban Land and the Politics of Property, New York.

Butler T., Lees L. (2006), Super-gentrification in Barnsbury, London: Globalization and Gentrifying Global Elites at the Neighbourhood Level, Transactions of the Institute of British Geographers, 31, s. 467-487.

Domański H. (2012), Polska klasa średnia, Toruń.

Drozda Ł. (2017), Uszlachetniając przestrzeń. Jak działa gentryfikacja i jak się ją mierzy, Warszawa.

Gądecki J. (2012), I love NH. Gentryfikacja starej części Nowej Huty?, Warszawa.

Glass R. (2010), London: Aspects of Change, [w:] L. Lees, T. Slater, E. Wyly (red.), The Gentrification. Reader, London, s. 5-15.

Groyecka D. (2014), Gentryfikacja Berlina. Od życia na podstuch do kultury caffe latte, Gdańsk.

Grzeszczak J. (2010), Gentryfikacja osadnictwa. Charakterystyka, rozwój koncepcji badawczej i przegląd wyjaśnień, Warszawa.

Jacobs J. (2014), Śmierć i życie wielkich miast Ameryki, Warszawa.

Kajdanek K. (2011a), Pomiędzy miastem a wsia. Suburbanizacja na przykładzie osiedli podmiejskich Wrocławia, Kraków.

Kajdanek K. (2011b), Suburbanizacja w Polsce - pejzaż społeczno-przestrzenny, Przegląd Socjologiczny, 60, s. 303-321.

Kajdanek K. (2012), Suburbanizacja po polsku, Kraków.

Kajdanek K. (2014), Dom na suburbiach. Ideat podmiejskiego zamieszkiwania a strategie udomowienia, [w:] M. Łukasiuk, M. Jewdokimowa (red.), Socjologia zamieszkiwania, Warszawa, s. $181-214$.

Kajdanek K. (2019), Powrót z suburbiów do miasta. Wstępne uwagi, [w:] E.J. Lipińska (red.), Zbigniew Rykiel i przestrzeń społeczna, Rzeszów, s. 53-62.

Kowalczuk K. (2015), Kto marzy o życiu w mieście, a kto o życiu na wsi, Komunikat $z$ badań CBOS, nr 18.

Lees L. (2008), Gentrification and Social Mixing: Towards an Inclusive Urban Renaissance? Urban Studies, 45(12), s. 2449-2470. 
Leśniak-Rychlak D. (2018/2019), Jesteśmy wreszcie we własnym domu, Kraków.

Murzyn M.A., Kazimierz: Środkowoeuropejskie doświadczenie rewitalizacji, Kraków 2006.

Nóżka M. (2016), Społeczne zamykanie (się) przestrzeni. O wykluczeniu, waloryzacji miejsca zamieszkania i jego mentalnej reprezentacji, Warszawa.

Phillips M. (1993), Rural Gentrification and the Processes of Class Colonisation? Journal of Rural Studies, 9(2), s. 123-140.

Sinewali V. (2010), Gentryfikacja. Lokatorzy w ogniu wojny socjalnej, Poznań.

Smith D., Phillips D.A. (2001), Socio-Cultural Representations of Greentrified Pennine Rurality, Journal of Rural Studies, 17(4), s. 457-469.

Smith N. (1996), The New Urban Frontier: Gentrification and the Revanchist City, London-New York.

Stelmaszewska N. (2020), Konsekwencje suburbanizacji dla miast i stref podmiejskich w świetle literatury krajowej i zagranicznej, Urban Development Issues, 66, s. 25-34.

Szlendak T. (2010), O stylach życia w mozaikowym społeczeństwie (od których zależeć będzie rozwój gospodarczy), [w:] B Łaciak (red.), Polskie style życia, Między miastem a wsia - V Kongres Obywatelski, Gdańsk, s. 13-21.

Szukalski P. (2015), Suburbanizacja obszarów wielkomiejskich w Polsce. Demografia i Gerontologia Społeczna - Biuletyn Informacyjny, nr 4, s. 1-4.

Śpiewak R.(2016), Wiejska gentryfikacja: definicja, znaczenie i skutki procesu, [w:] M. Halamska, S. Michalska, R. Śpiewak (red.), Studia nad struktura społeczna wiejskiej Polski, Warszawa, s. $129-156$.

Wójcik M. (2013), Przemiany społeczno-przestrzenne osiedli wiejskich. Studium przypadku Łódzkiego Obszaru Metropolitalnego, Łódź.

Zierke P. (2016), Tradycyjna architektura Golęczewa i jej wpływ na zabudowę współczesną, Space Society-Economy, 17, s. 101-113.

Zwęglińska-Gałecka D. (2020), Gentryfikacja wsi: próba określenia przestrzennego zasięgu zjawiska, Studia Regionalne i Lokalne, 3(81), s. 115-145.

Zwęglińska-Gałecka D., Hasik Z. (2018), Gentryfierzy w społeczności wiejskiej: opis wybranych elementów stylu życia. Case study gminy Prażmów, Intercathedra, 4(37), s. 425-430.

Źróbek-Różańska A., Zysk E. (2015), Czy rozlewające się miasto odmładza podmiejską wieś? Studium podolsztyńskich gmin wiejskich, Wieś i Rolnictwo, 4(169), s. 123-137. 